УДК: $371.10(438)$

DOI:

Лариса Сливка, кандидат педагогічних наук, дочент кафедри педагогіки початкової освіти ДВНЗ "Прикарпатський національний університет імені Василя Стефаника"

\title{
ЗДОРОВ'ЯЗБЕРЕЖУВАЛЬНА ТЕМАТИКА У ЗМІСТІ НАВЧАЛЬНИХ ДИСЦИПЛІН ЗАГАЛЬНООСВІТНІХ ШКІЛ ПОЛЬЩІ В 1950-1970-Х РР.
}

У 1950-1970 х рр. в загальноосвітніх школах Польщі здоров'язбережувальна тематика знаходила вияв у змісті низки навчальних дисциплін, у процесі реалізаџії авторських спецкурсів відповідного спрямування і під час годин класного керівника. У статті проаналізовано потенційні можливості у зазначеному контексті курсів “Фізичне виховання” $i$ “Біологія”. Озвучено завдання фізичного виховання, які декларувалися в навчальній програмі иієї дисципліни підтримання і примноження здоров'я, формування естетики постави і рухів, формування уявлень $і$ знань про вплив фізичних вправ на тіло і психіку людини, ознайомлення з основними вимогами гігієни спорту тощь. Деталізовано змістове наповнення розділів “Біології”, присвячених питанням особистої і суспільної гігієни, профілактиці інфекиійних захворювань і икідливих звичок, т.ін.

Ключові слова: здоров 'язбережувальне виховання; Польща; загальноосвітня школа, 1950-1970-х рр., навчальні програми.

Jim. 9.

Larysa Slyvka, Ph.D.(Pedagogy), Associate Professor of the Pedagogy of Primary Education Department SHEI"Vasyl Stefanyk Precarpathian National University"

\section{HEALTH-PRESERVING SUBJECTS IN THE CONTENT OF EDUCATIONAL DISCIPLINES OF SECONDARY SCHOOLS OF POLAND IN THE 1950s - 1970s}

The social demand for health, characteristic of the current stage of development of Ukraine as a European state, highlights the need to saturate the content of domestic pedagogy with new information on preserving, strengthening and shaping the health of children and youth, studying, analyzing and rethinking relevant European experience in the context of educational aspects of health of a growing personality. In this sense, the genesis of "Polish" health education deserves attention the theoretical and practical aspects of this pedagogical phenomenon can be used in the Ukrainian educational space.

The article announces the names of Khanna Ventlandtova (pol. Hanna Wendtlandtowa; 1906-1994) and Matsei Demel (pol. Maciej Demel), whose works most vividly represent the development of the theoretical foundations of health education in Poland after the Second World War. To a greater or lesser extent, health-preserving educational influences have permanently found their practical embodiment in the content of many disciplines, which in the 1950s 1970s were taught in secondary schools in Poland ("Physical Education", "Biology", "Patriotic upbringing "Information about nature", "Handicraft", "Drawing", "Music"), in the process of implementing author's special courses in the relevant field and during the hours of the class teacher in the form of lectures and conversations.

The study analyzes in more detail the potential opportunities in this context of the courses "Physical Education" and "Biology". The purpose and objectives of physical education, which were declared in the curriculum of this discipline - maintaining and increasing health, the formation of aesthetics of posture and movement, the formation of ideas and knowledge about the impact of exercise on the human body and psyche, familiarization with the basic requirements of sports hygiene. The content of separate sections of "Biology" devoted to questions of personal and public hygiene, prevention of infectious diseases and harmful habits, etc. is detailed. Emphasis is placed on the expediency of creative use of this historical experience in modern Ukrainian pedagogy.

Keywords: health-preserving education Poland; secondary school; 1950s - 1970s; curricula.

П остановка проблеми. Соціальний запит на здоров'я, характерний для сучасного етапу розвитку України як європейської держави, актуалізує потребу насичення змісту вітчизняної педагогіки новою інформацією з проблеми збереження, зміцнення і формування здоров'я дітей та юнацтва, вивчення, аналізу й переосмислення доцільного європейського досвіду в контексті виховно-освітніх аспектів здоров'язбереження зростаючої особистості. У цьому сенсі заслуговує на увагу генеза “польського” здоров'язбережувального виховання теоретичні і практичні аспекти цього педагогічного феномену можуть бути доцільно використані в українському освітньому просторі.

Аналіз останніх досліджень і публікацій Дослідниками України (А. Бесєдіною, Е. Вільчковським, Р. Гахом, Т. Срмаковою, О. Карпенко, І. Мордвіновою, В. Пасічником, М. Перфільєвою, ін.) виявлено і охарактеризовано досить розмаїтий контекст освітньо-виховних векторів розв'язання проблеми здоров' язбереження зростаючої особистості у її 


\section{ЗДОРОВ'ЯЗБЕРЕЖУВАЛЬНА ТЕМАТИКА У ЗМІСТІ НАВЧАЛЬНИХ ДИСЦИПЛІН}

ЗАГАЛЬНООСВІТНІХ ШКІЛ ПОЛЬЩІ В 1950-1970-Х РР.

загальноєвропейському вимірі. Водночас, ретроспектива “"польського” здоров'язбережувального виховання в українській науці представлена недостатньо.

Мета статті полягає в аналізі наповнення здоров'язбережувальною тематикою навчальних дисциплін у загальноосвітніх школах Польщі в 1950-1970-х рр. для творчого використання історичного досвіду в сучасній педагогіці.

Виклад основного матеріалу. Після Другої світової війни проблему збереження здоров'я дітей та молоді розв'язували у Польській Народній Республіці (ПНР) насамперед у контексті відродження шкільництва і опіки над осиротілими і безпритульними дітьми. Виразні спроби включення здоров'язбережувальної тематики у теорію і практику загальної педагогіки датуються 50 ми pp. XX ст. Зокрема, у стінах університету в

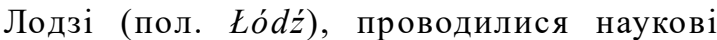
дослідження щодо методики освіти в означеній сфері, яку декларували як “санітарна освіта" [1, 18 19]. Результати цієї діяльності стали вагомим підгрунтям появи в 1960-1970-х рр. грунтовних теоретичних працьзпроблемиздоров'язбережувального виховання досить згадати творчі напрацювання Ханни Вентландтової (пол. Hanna Wentlandtowa; 1906 1994) [7] і Мацєя Демеля (пол. Maciej Demel; 1923 2017) [4].

Тією чи іншою мірою здоров'язбережувальні виховні впливи перманентно знаходили своє практичне втілення у змісті багатьох навчальних дисциплін, які в 19501970 х рр. викладалися у загальноосвітніх школах Польщі (“Фізичне виховання”, “Біологія”, “Відомості про природу”, “Патріотичне виховання", "Ручна праця", “Малювання”, “Музика”), в процесі реалізації авторських спецкурсів відповідного спрямування і під час годин класного керівника у формі лекцій і бесід $[1,21]$.

Докладніше проаналізуємо у цьому контексті зміст “Фізичного виховання" i “Біологіі”.

У 50 х рр. ХХ ст. у навчальних програмах для 11 річних загальноосвітніх шкіл мета фізичного виховання озвучувалася як підготовка молоді до здорового і активного життя, формування громадянина, здатного до праці і оборони держави шляхом “підтримання і примноження” здоров'я. Цей напрям виховання анонсувався як інтегральна частина комплексу виховних впливів, спрямованих на фізичний, розумовий, моральний і естетичний розвиток учня. Серед завдань фізичного виховання учнів загальноосвітніх шкіл чітко озвучувалися ті, які безпосередньо стосувалися здоров'язбереження іздоров'яформування вихованців, а саме: формування в учнів знань про вплив фізичних вправ на тіло і психіку людини, формування уявлень про гігієнічні вимоги щодо реалізації різних спортів, розвиток в учнів потрібних у щоденному житті моторних навичок (перевертання, нахили, ходьба, повзання, біг, стрибки, здатність маніпулювати дрібними предметами, передавати об'єкти з руки в руку, виконання завдань, що потребують скоординованої роботи очей і рук, ін.), а також навичок роботи в “команді", виховання в учнів щоденної потреби у русі, бажання займатися фізкультурною активністю, особливо на свіжому повітрі [8, 3-4].

У 1-4-х класах для уроків фізичного виховання відводилося дві години на тиждень, в 5-7-х класах дві щотижневі години доповнювалися додатковими двома годинами, призначеними для так званих “теренових” ігор і спортів (теренова гра: рольова або сценарійна гра, яка відбувається на відкритому терені за чіткими правилами Л. С.). У 8-11-х класах фізичне виховання теж відбувалося чотири години на тиждень: дві 3 них відводилися на уроки фізичного виховання, а дві додаткові на суто спортивні заняття. Змістовий контент фізичного виховання було розподілено у такі блоки: “рухливі забави” (у тому числі у воді, на снігу), “гімнастичні вправи”, “музично-рухливі вправи народні і регіональні танці”, “спорти і прогулянки”. Додамо, що для учнів I VII класів блок "гімнастичні вправи" передбачав головно “ігровий” аспект і озвучувався у навчальній програмі як “гімнастичні вправи лише у забавовій формі" [6, 38-44; 8, 5 74].

Перші післявоєнні програми 3 фізичного виховання (одна $з$ доступних датується 1949 р.) були “еластичними” вони пропонували досить розмаїті форми руху, що дозволяло кожній школі, відповідно до наявних локальних і теренових умов, обирати найдоступніший і найдоцільніший варіант реалізації фізичного виховання [8, 108].

Зазначимо, що важливе місце у змісті фізичного виховання відводилося формуванню у вихованців свідомого ставлення до власного здоров'я та вмінь безпечної поведінки в процесі фізкультурної діяльності. Навчальні програми з цієі дисципліни “зосереджували” увагу вчителів, до прикладу, на обов'язковості миття рук після забав і вправ, потребі формування в учнів навичок правильного дихання, уявлень про значення різних видів загартування для організму людини, тощо. Також актуальними вважалися проблеми щодо дотримання чистоти в спортивних залах роздягальнях, безпека спортивного оснащення, раціональний розклад уроків 3 фізичного виховання (приміром, не ставити уроки фізичного 


\section{ЗДОРОВ'ЯЗБЕРЕЖУВАЛЬНА ТЕМАТИКА У ЗМІСТІ НАВЧАЛЬНИХ ДИСЦИПЛІН ЗАГАЛЬНООСВІТНІХ ШКІЛ ПОЛЬЩІ В 1950-1970-Х РР.}

виховання в години, коли учні тільки-но поїли), налагодження тісної співпраці учителя, який реалізує фізичне виховання, ішкільного лікаря $[8,109]$.

Щодо уроків “Біології”, то в 1950-х pp. ïi вивчали 3 третього класу по дві години на тиждень, але здоров'язбережувальна тематика фігурувала лише у 4-7-х класах.

У навчальній програмі з біології для 4-го класу надибуємо підрозділ “День здорової людини”, який засвідчує, що для вивчення цієї теми було відведено 20 годин, а саме: особиста гігієна (3 год.), гігієна помешкання (1 год.), раціональне харчування (1 год.), гігієна вдома (4 год.), інфекційні захворювання і способи профілактики (7 год.), догляд за хворим (1 год.), шкідливий вплив алкоголю (1 год.), раціональний режим дня (1 год.), роль держави і громадськості у піднесенні гігієни (1 год.) [2, 10-11].

Починаючи з 5-го класу, “біологічний” контент було чітко диференційовано, що знайшло свої увиразнення і у назвах відповідних навчальних курсів. У 7-му класі загальноосвітніх шкіл вивчали “Науку про людину”. Відведені для цього курсу 60 годин призначалися для опанування учнями розмаїтої інформації, як-от: опорно-рухова, дихальна, кровоносна системи; травна система i раціональне харчування; перша долікарська допомога; значення для здоров'я фізичних вправ; наркотичні речовини і їх вплив на організм, шкідливий вплив алкоголю; глистні інвазії; гігієна шкіри, волосся і одягу; гігієна нервової системи, гігієна фізичної і розумової праці, значення відпочинку і сну; нюх, слух, смак і дотик; гігієна очей; суспільна гігієна; перспективи розвитку спорту у Польщі [2, 26-30].

Проведена у 1961 р. освітня реформа, яка внесла зміни до структури шкільництва (11 річна загальноосвітня школа стала 12 річною і була представлена 8 річною подставовою школою і 4 річним ліцеєм), “оновила” й навчальні плани як у кількісному, так і у якісному вимірі.

Для уроків “Фізичного виховання”, як і в попередні роки, відводилося дві години на тиждень у всіх класах, а, починаючи з 5-го класу, ще були дві “додаткові” години на тиждень. У 3-6-х класах з'явився курс “Відомості про природу”, вивчення якого тривало дві години на тиждень [5]. Біологія і надалі, поряд зі завданнями, спрямованими на засвоєння біологічних знань, відігравала важливу роль у здоров'язбережувальному вихованні учнів і прищепленні їм відповідних навичок. До прикладу, в 7-му класі під час вивчення анатомії людини (64 години на рік) учні отримували знання про анатомію і фізіологію людини, особисту гігієну і гігієну оточення, вплив фізичного навантаження на організм людини, тощо. $[1,22]$. Здоров'язбережувальний контент було представлено також у змісті навчальної дисципліни “Патріотичне виховання" (в 7-му класі іiі вивчали один раз на тиждень, у 8-му два рази на тиждень). Так, у контексті загальнолюдських і національних цінностей, формування почуття колективізму, толерантності, взаємодопомоги та взаємопідтримки тощо, розглядалася проблематика, дотична до правил гігієни сну, особистої гігієни, профілактики травматизму, негативного впливу куріння і алкоголю на здоров'я людини та ін. [3].

У 60-70-х рр. ХХ ст. в школах ПНР впроваджувалися й авторські виховні програми в контексті питань про здоров'я. До прикладу, 1967/ 1968 навчального року для учнів 1-8 класів загальноосвітніх шкіл м. Гданськ реалізовувалася одна 3 таких програм. Вона передбачала тісну співпрацю учителів і лікарсько-гігієнічного персоналу, залучення батьків учнів до контролю за здоров'ям дітей вдома, активізацію діяльності дитячих та молодіжних організації у межах школи щодо здоров'язбережувального виховання, використання потенційних можливостей “світлиць” груп продовженого дня у реалізації цього виховання засобами ігор, бесід, конкурсів, ін. [9].

Висновки. 3 усього можемо зробити висновок, що впродовж 1950-1970-х рр. здоров'язбережувальне виховання узагальноосвітніх школах Польщі реалізовувалося засобами різних навчальних дисциплін. Найрозлогіше означений контент був представлений у змісті “Фізичного виховання" та "Біології". Додатково відповідні виховні впливи здійснювалися впровадженням у навчально-виховний процес низки авторських спецкурсів і виховних програм.

\section{ЛІТЕРАТУРА}

1. Єрмакова Т.С. Теорія і практика формування культури здоров'я школярів у Польщі (друга половина XX початок XXI століття) : автореф. дис. ... на здобуття наукового ступеня доктора пед. наук. Харків, 2017. 42 с.

2. Biologia: program nauki w 11-letnej szkole ogólnokształcącej: projekt. Warszawa: Państwowe zakłady wydawnictw szkolnych, 1949. 78 s. URL: https://pbc.gda.pl/dlibra/publication/13739/edition/ 17977/content

3. Czartoryjski W. Czasopismo dla nauczycieli. Wychowanie patriotyczne w pracy nauczyciela wychowania fizycznego. Wychowanie fizyczne $w$ skole. 1953. nr 2. S. 1-6.

4. Demel M. O wychowaniu zdrowotnym. Warszawa: PZWS, 1968. 192 s. 
5. Kutzner J. Programy wychowania fizycznego w zreformowanej szkole. Nowa szkola. 1965. nr. 11. S. 54-58.

6. Mitkiewicz K. Zagadnienie higieny w pracy wychowawcy fizycznego na terenie szkoły. Wychowanie fizyczne $w$ szkole. 1953. nr. 6. S. 3844.

7. Wentlandtowa H. Metodyka oświaty sanitarnej: dla wychowawców, nauczycieli, oświatowców, pracowników świetlic, domów kultury i służby zdrowia. Warszawa: Państwowy Zakład Wydawnictw Lekarskich, 1960. $123 \mathrm{~s}$.

8. Wychowanie fizyczne: program nauki w 11letniej szkole ogólnokształcącej: projekt. Warszawa: Państwowe zakłady wydawnictw szkolnych, 1949. 126 s. URL: https://pbc.gda.pl/dlibra/publication/ 13572/edition/17976/content

9. Wychowanie zdrowotne w szkole. Materialy Krajowego Sympozjum Wychowania Zdrowotnego (13-14.X.1971 r., Kielce). Warszawa, 1974. S. 356375.

\section{REFERENCES}

1. Yermakova, T.S. (2017). Teorya i praktyka formuvannya kultury zdoroviya shkolyariv u Polshchi (druga polovyna XX pochatok XXI stolittya). [Theory and practice of forming a culture of school health in Poland (second half of the XX beginning of the XXI century)]. Extended abstract of Doctor's thesis. Kharkiv. 42 p. [in Ukrainian].

2. Biologiya: program nauki v 11-letnej shkole ogulnokshtalconcey: proyekt. (1949). [Biology: study program in 11-year general school: project]. Warsaw: State schools publishing houses. $78 \mathrm{p}$. Available at: https://pbc.gda.pl/dlibra/publication/13739/edition/ 17977/content. [in Poland].
3. Chartoryyski, V. (1953). Chasopismo dla nauchycieli. Vychovaniye patriotychne $\mathrm{v}$ pracy nauchycyela vychovania fizychnego [Magazine for teachers. Patriotic education in the work of a physical education teacher]. Physical education in the school. No.2. pp. 1-6. [in Poland].

4. Demel, M. (1968). O vychovaniyu zdrovotnym [About health education]. Warsaw: PZVS. 192 p. [in Poland].

5. Kutzner, J. (1965). Programy wychowania fizycznego w zreformowanej szkole [Physical education programs in a reformed school]. New school. No.11.pp. 54-58. [in Poland].

6. Mitkiyevich, K. (1953). Zagadniyeniye higiyeny v pracy vychovavcy fizychnego na tereniye shkoly [The issue of hygiene in the work of a physical educator at school]. Physical education at school. No. 6. pp. 38-44. [in Poland].

7. Ventlandtova, H. (1960). Metodyka osviyaty sanitarnej: dla vychovavcuv, nauchycyeli, osviatovcuv, pracovnikuv sviyetlic, domuv kultury i sluzhby zdroviya [Methodology of sanitary education: for educators, teachers, educators, employees of community centers, community centers and health services]. Warsaw: State Institute of Medical Publishing. 123 p. [in Poland].

8. Vychovanye fizychne: program nauki v 11letniey shkole ogulnokshtalconcey: proyekt. (1949). [Physical education: 11-year general education program: project]. Warsaw: State school publishing houses. 126 p. Available at: https://pbc.gda.pl/dlibra/ publication/13572/edition/17976/content. [in Poland].

9. Vychovanie zdrovotne v shkole (1974). [Health education at school]. Materials of the National Symposium for Health Education, 13-14 October 1971, Kielce. Warsaw. pp. 356-375. [in Poland].

\section{G58080} "Успіхи науки - diло часу і сміливості розуму".

"Точатки, закладені в дитинстві людини, схожі на вирізані на корі молодого дерева букви, що ростуть разом з ним, іскладають невід 'ємну частину його”.

Biкmop Tюго франиузький письменник, поет, драматург

"Емоиійне сприймання - ие взагалі азбуқа всякого виховання; тільки той, хто оволодів нею в дитячі роки, здатний швидко і свідомо читати світ людини".

Василь Сухомлинський педагог, публішист, письменник

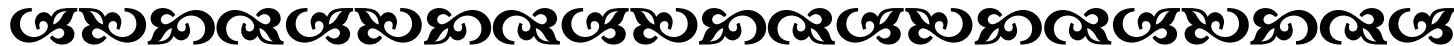

